\title{
Analisis Kebijakan Bebas Visa Kunjungan Singkat (BVKS) Terhadap Sektor Pariwisata di Kota Makassar
}

\section{The Impact of Short-Stay Visa Policy on The Tourism Sector in Makassar City}

\author{
Andi Meganingratna ${ }^{1}$, Adelita Lubis ${ }^{2}$, Rizky Aftaria ${ }^{3}$, Alvin Septian ${ }^{4}$ \\ ${ }^{1,2,3,4}$ Program Studi Ilmu Hubungan Internasional, Fakultas Ekonomi dan Ilmu-ilmu Sosial, \\ Universitas Fajar Makassar
}

Email:ningratna07@gmail.com ${ }^{1}$,adelitalubis@gmail.com²,rizkyaftaria@gmail.com ${ }^{3}$,alvinseptian@gmail.com ${ }^{4}$

Diterima: 23 November 2020 Direvisi:24 Juni 2021 Disetujui: 30 Juni 2021

DOI: $10.35967 /$ njip.v20i1.116

\begin{abstract}
Abstrak: Arus globalisasi memberikan dampak yang besar terhadap perpindahan masyarakat dari satu negara ke negara yang lain. Manusia berpindah dengan berbagai macam tujuan, beberapa di antaranya didorong karena faktor ekonomi ada pula yang melakukan kunjungan ke negara lain untuk berwisata. Otoritas sebuah negara memberlakukan syarat-syarat untuk warga asing ketika memasuki wilayahnya. Visa merupakan syarat dokumen yang harus dilengkapi oleh seseorang yang bermaksud untuk memasuki wilayah otoritas negara lain. Penelitian ini bertujuan untuk melihat implikasi yang ditimbulkan oleh kebijakan Bebas Visa Kunjungan yang diberlakukan pemerintah Indonesia terhadap peningkatan pariwisata Indonesia, khususnya di Kota Makassar. Penelitian ini menggunakan metode deskriptif dengan pendekatan kualitatif dengan menggunakan teori kepentingan nasional dan kebijakan nasional. Dengan perangkat-perangkat tersebut penelitian ini diharapkan dapat menjelaskan implikasi apa yang ditimbulkan oleh penerapan kebijakan bebas visa kunjungan terhadap pariwisata di Kota Makassar. Hasil dari penelitian ini ditemukan bahwa KBVKS memberikan dampak yang signifikan terhadap pariwisata kota Makassar namun harus diformulasikan dengan bentuk kebijakan daerah yang mendukung promosi-promosi pariwisata agar kota Makassar menjadi destinasi wisata para pelancong mancanegara.
\end{abstract}

Kata Kunci: Visa Kunjungan, Pariwisata, Kota Makassar.

\begin{abstract}
The flow of globalization has a major impact on the movement of people from one country to another. Humans move for a variety of purposes, some of which are driven by economic factors and there are for tourism as well. The authorities of a country impose conditions on foreigners when entering its territory. A visa is a document requirement that a person intending to enter the territory of another country must complete. This study aims to see the implications of the Policy of Short-Stay Visa imposed by the Indonesian government on increasing foreign tourist, especially in Makassar City. This study uses a descriptive method with a qualitative approach using the theory of national interests and national policies. With these tools, it is hoped that this research will explain the implications of the implementation of the visa-free visit policy on tourism in Makassar City. The result of this study found that BVKS has a significant effect towards Makassar Tourism however, it must be formulated with policies that encourage promotion of Makassar Tourism.
\end{abstract}

Keywords: Visa, Tourism, Makassar City.

\section{Pendahuluan}

Keimigrasian Indonesia sebagai lembaga dalam struktur kenegaraan merupakan organisasi vital sesuai dengan sasanti Bhumi Pura Purna Wibawa yang berarti penjaga pintu gerbang negara yang berwibawa (Hamidi, 2015). Seiring berkembangnya waktu negara-negara mulai membuat hukum keimigrasiannya sendiri sehingga untuk memasuki suatu wilayah negara dibutuhkan dokumen perjalanan yang dikenal sebagai paspor untuk melakukan perjalanan lintas negara. 
Nakhoda: Jurnal Ilmu Pemerintahan

Vol. 20 No. 01 Tahun 2021 Halaman 80-92

e-ISSN: 2656-5277 | p-ISSN: 1829-5827

Paradigma baru melihat bahwa keimigrasian itu bersifat multidimensional, baik itu dalam tatanan nasional maupun internasional. Hal ini disebabkan karena masalah keimigrasian adalah masalah yang dinamis, sehingga ruang lingkup keimigrasian mencakup dalam berbagai bidang (Hamidi, 2015). Pada dasarnya fungsi keimigrasian bersifat universal, yaitu mengatur lalu lintas orang masuk dan keluar wilayah suatu negara sesuai dengan kebijakan yang telah dikeluarkan oleh pemerintah. Keimigrasian di Indonesia berlandaskan kepada Undang-Undang Nomor 6 Tahun 2011 yang berisi tentang hukum keimigrasian dengan tujuan pengawasan orang asing di Indonesia dan menjaga kedaulatan negara. Prinsip kedaulatan ini memberikan kewenangan absolut kepada pemerintah untuk membuat regulasi terkait dengan lalu lintas orang yang masuk dan keluar dari wilayah Negara Kesatuan Republik Indonesia.

Seiring dengan perkembangan global, beberapa negara tidak lagi mewajibkan wisatawan asing memiliki visa untuk melakukan kunjungan. Visa adalah dokumen izin masuk seseorang yang bukan warga suatu negara ke negara lain di mana dokumen ini bisa diperoleh di kedutaan di mana negara tersebut mempunyai Konsulat Jenderal atau kedutaan asing. Memiliki visa berarti rencana kunjungan seseorang ke sebuah negara mendapat persetujuan dari negara tersebut. Visa bisa berbentuk stiker visa yang dapat didapatkan dari kedutaan negara yang akan dikunjungi atau berbentuk stempel pada paspor di negara tertentu.

Negara-negara dari lingkup anggota ASEAN dapat masuk ke wilayah Indonesia tanpa menggunakan visa untuk tujuan kunjungan singkat selama 30 hari dan untuk negara-negara lain di luar keanggotaan ASEAN menggunakan visa berjenis Visa on Arrival (VoA). Beberapa negara menggunakan Visa on Arrival (VoA) sebagai jenis visa untuk keperluan kunjungan, urusan bisnis dan juga sebagai izin tinggal di negara tertentu. VoA sendiri dapat diperoleh secara langsung di Bandara maupun Pelabuhan di negara yang dituju pada konter khusus untuk VoA, tanpa harus mengurus dokumen perjalanan di negara asalnya. Prosedur pembuatan VoA seperti mengisi formulir yang diberikan oleh pejabat imigrasi di negara tujuan dengan menyertakan asal negara, rencana kunjungan, dan berbagai pertanyaan lainnya. Dengan biaya administrasi yang beragam tergantung dari tujuan negara yang di tuju dan mendapatkan cap atau stiker dari pejabat imigrasi negara tujuan sebagai bukti sah memasuki sebuah wilayah negara (Consular Indonesia, n.d, 2019).

Pada masa pemerintahan Joko Widodo sebagai Presiden Republik Indonesia membuat Kebijakan baru pada bidang keimigrasian dengan meresmikan kebijakan bebas visa kunjungan Indonesia pada tanggal 2 Maret 2016 yang telah di tanda tangani dalam Perpres Nomor 21 Tahun 2016, di mana tercatat 169 negara berhak mendapatkan izin tinggal dengan pengecualian hanya dapat digunakan untuk keperluan wisata serta keperluan bisnis dan dapat digunakan selama 30 Hari tanpa bisa di perpanjang (Hukumonline, 2016). Kebijakan ini meliputi bidang ekonomi dan mencakup beberapa subsektor salah satu di antaranya adalah sektor industri pariwisata.

Kepariwisataan merupakan salah satu subsektor pembangunan nasional khususnya di negara Indonesia, yang dapat mendorong pertumbuhan ekonomi, dengan meningkatkan perolehan devisa, kesempatan usaha dan kesempatan kerja (A.J. Muljadi, 2009). Sektor pariwisata memang cukup menjanjikan untuk turut membantu menaikkan cadangan devisa suatu negara, selain itu pariwisata juga bisa mendongkrak ekonomi dalam negeri dengan munculnya berbagai macam industri kreatif dari masyarakat.

Banyak faktor yang dapat mempengaruhi perkembangan kepariwisataan sebuah negara, di antaranya persoalan keamanan sebuah negara, situasi politik dalam negeri, bencana alam, kesehatan, birokrasi imigrasi dan persoalan lainnya. Faktor-faktor tersebut akan mempengaruhi kunjungan wisatawan asing yang datang ke sebuah negara. Untuk dapat memperoleh kembali devisa negara dari sektor pariwisata serta meningkatkan daya saing wisata, maka negara tersebut harus mampu menggairahkan kembali industri pariwisata dan meningkatkan jumlah kunjungan wisatawan mancanegara dengan mengeluarkan berbagai bentuk kebijakan (A.J. Muljadi, 2009).

Di era kepemimpinan Presiden Jokowi muncul kebijakan-kebijakan yang mengarah ke 
pembangunan pariwisata Indonesia, salah satu di antaranya adalah Kebijakan Bebas Visa Kunjungan Singkat. Kebijakan bebas visa kunjungan ini sebagai bentuk upaya Indonesia membangun hubungan dengan negara lain demi mencapai Kepentingan Nasional di Bidang Pariwisata dengan menggunakan konsep Kebijakan Nasional itu sendiri guna bertujuan untuk meningkatkan perkembangan ekonomi negara ke depannya melalui pendapatan devisa negara serta melihat tingkat kunjungan wisatawan asing khususnya di Provinsi Sulawesi Selatan terkait kebijakan tersebut. Hingga saat ini sejak diratifikasikannya kebijakan bebas visa kunjungan sejak tahun 2016 terus berjalan dan memudahkan warga negara asing untuk masuk ke Indonesia, khususnya kota Makassar sebagai salah satu wilayah tujuan warga negara asing untuk wisata dan memiliki dampak yang besar dalam pertumbuhan Ekonomi Negara.

Melihat upaya-upaya yang dilakukan Pemerintah Indonesia dalam hal kepariwisataan dengan mengeluarkan kebijakan bebas visa kunjungan sebagai kebijakan baru pada Keimigrasian Indonesia, penting untuk dilakukan analisis kebijakan bebas visa kunjungan terhadap sektor pariwisata di Kota Makassar. Dalam tulisan ini penulis memfokuskan pada keefektifan kebijakan bebas visa kunjungan dalam mencapai Kepentingan Nasional, maka dari itu penulis akan membahas tentang bagaimana analisis Kebijakan Bebas Visa Kunjungan terhadap sektor pariwisata di Kota Makassar serta peran pemerintah terkait Kebijakan Bebas Visa Kunjungan.

Unit analisis yang digunakan pada penelitian adalah individu yang berperan untuk menganalisis fenomena dengan menggunakan teori dan konsep. Teori dan konsep yang digunakan sesuai dengan objek penelitian dan pokok permasalahan yang di teliti. Adapun teori dan konsep yang digunakan adalah sebagai berikut: Pertama, Kepentingan Nasional adalah tujuan mendasar serta faktor paling penting yang menentukan dan memandu para pembuat keputusan dalam merumuskan politik luar negeri (Jack C. Plano, 1969). Peran negara sebagai aktor yang mengambil keputusan dan memerankan peranan yang penting dalam dunia Internasional yang berpengaruh bagi masyarakat dalam negerinya. Menurut Thomas Hobbes, negara dipandang sebagai pelindung wilayah, penduduk, dan cara hidup yang khas dan berharga. Demikian Karena negara merupakan sesuatu yang esensial bagi kehidupan warga negaranya. Tanpa negara yang menjamin alat-alat maupun kondisi-kondisi keamanan ataupun dalam memajukan kesejahteraan kehidupan masyarakat jadi terbatasi (Robert Jackson, 2005). Lalu menurut Hans J. Morgenthau, Kepentingan nasional adalah kemampuan minimum negara untuk melindungi, dan mempertahankan identitas fisik, politik, dan kultur dari gangguan negara lain. Dari tinjauan ini para pemimpin negara menurunkan kebijakan spesifik terhadap negara lain yang sifatnya kerja sama atau konflik (Morgenthau, 1951). Jadi dapat di simpulkan bahwa Kepentingan Nasional tercipta dari kebutuhan suatu negara yang dielaborasi dengan sumber daya yang dimiliki oleh negara tersebut baik dari segi politik, keamanan, sosial dan budaya. Sumber daya tersebut yang digunakan untuk membentuk branding sebuah negara dalam menjalin hubungan dengan negara lain

Sebelumnya di Indonesia sendiri hanya menggunakan tiga jenis visa untuk masuk ke dalam wilayah Indonesia, di antaranya ;

- ITK (Izin Tinggal Kunjungan)

- ITAS (Izin Tinggal Terbatas)

- ITAP (Izin Tinggal Tetap)

Dalam kepentingan nasional, negara adalah aktor dalam mengambil dan pembuat keputusan demi kepentingan negaranya. Di mana Pemerintah melihat potensi pariwisata di Indonesia sangat besar dan mengeluarkan berbagai jenis kebijakan salah satunya kebijakan bebas visa kunjungan yang dibuat untuk meningkatkan tingkat kunjungan pada Sektor Pariwisata dengan menggunakan unsur kebudayaan sebagai bentuk dari kepentingan nasional.

Kedua, Kebijakan yang diterjemahkan dari kata policy memang biasanya dihubungkan dengan keputusan pemerintah, karena pemerintahlah yang mempunyai kekuasaan atau 
wewenang untuk mengarahkan masyarakat, dan bertanggung jawab melayani kepentingan lainnya (Budiardjo, 2003). Dalam sebuah sistem pemerintahan, kebijakan dilaksanakan oleh badan-badan pemerintah melalui regulasi yang dibuat oleh pemerintah. Badan-badan tersebut melaksanakan pekerjaan-pekerjaan pemerintah dengan tujuan untuk menciptakan kehidupan yang baik bagi warganegaranya. Kebijakan Pemerintah menurut Thomas R. Dye mengatakan Kebijaksanaan pemerintah merupakan apa saja yang ditetapkan oleh pemerintah untuk dilakukan atau tidak dilakukan. Definisi Thomas R. Dye itu didasarkan pada kenyataan, bahwa banyak sekali masalah-masalah yang harus diatasinya, banyak sekali keinginan dan kehendak rakyat yang harus dipenuhinya (Soenarko, 2003).

Kebijakan Pemerintah memiliki berbagai tingkatan tertentu, di antaranya Kebijakan Nasional, Kebijakan Umum, dan Kebijakan Strategi. Sebagai pengolahan data, penulis menggunakan konsep Kebijakan Nasional karena bentuk kebijakan nasional terkait dengan dibuatnya kebijakan baru di bidang keimigrasian untuk meningkatkan kunjungan wisatawan asing juga untuk meningkatkan pendapatan devisa negara melalui sektor pariwisata sebagai bentuk dari Kepentingan Nasional.

\section{Metode}

Menurut Susan E. Wyse pendekatan kualitatif adalah penelitian yang lebih bersifat eksplorasi. Penelitian ini digunakan untuk memperoleh pemahaman tentang alasan, opini, dan motivasi yang mendasari suatu perilaku. Penelitian ini ditujukan untuk memperoleh wawasan dalam suatu masalah serta membantu untuk mengembangkan ide-ide atau hipotesis dalam penelitian kuantitatif. Tujuan utama dari penelitian kualitatif adalah untuk memberikan penjelasan rinci dan lengkap terhadap topik penelitian (Bakry, 2016). Terkait dengan judul Analisis Kebijakan Bebas Visa Kunjungan Terhadap Sektor Pariwisata di Provinsi Sulawesi Selatan, penulis akan menggunakan metode penelitian kualitatif.

Teknik analisa data yang digunakan dalam penelitian ini adalah teknik reduksi data. Reduksi data berarti merangkum, memilih hal-hal yang menjadi inti dalam penelitian, memfokuskan pada hal-hal yang penting, mencari tema dan polanya, dengan demikian data yang telah direduksi akan memberikan gambaran yang jelas, dan mempermudah peneliti untuk mengumpulkan data selanjutnya (Matthew B. Miles, A. Michael Huberman, 2014).

\section{Hasil dan Pembahasan}

\section{Kebijakan Bebas Visa Kunjungan Terhadap Peningkatan Wisatawan Asing}

Dalam kehidupan sosial modern yang semakin padat, pariwisata tidak lagi dipandang sebagai kebutuhan tersier yang bersifat mewah. Pariwisata kini tidak hanya terbatas pada kalangan ekonomi ke atas saja, melainkan sudah menjadi kebutuhan seluruh lapisan masyarakat. Hal ini terjadi tidak hanya di negara maju tetapi mulai dirasakan pula di negara berkembang. Indonesia sebagai negara yang sedang berkembang berusaha membentuk exposure dengan membangun industri pariwisata, mengingat potensi wisata alam di Indonesia yang sangat beragam maka industri ini dinilai sangat menjanjikan untuk meningkatkan taraf ekonomi dalam negeri. Melalui industri ini diharapkan sektor perekonomian Indonesia meningkat. Sebagaimana diketahui bahwa sektor pariwisata di Indonesia masih menduduki peranan yang sangat penting dalam menunjang pembangunan nasional sekaligus merupakan salah satu faktor yang sangat strategis untuk meningkatkan pendapatan masyarakat dan devisa negara (Pendit, 1990).

Peningkatan serta perkembangan sektor Pariwisata di Indonesia tiap tahunnya meningkat dikarenakan munculnya sebuah kebijakan baru dalam lingkup keimigrasian, sebuah kebijakan yang dapat memudahkan wisatawan mancanegara untuk masuk ke dalam wilayah negara Indonesia menggunakan Visa jenis baru yaitu Bebas Visa Kunjungan. Sebelumnya di Indonesia berlaku tiga jenis Visa yang di gunakan oleh Warga Negara Asing yang ingin memasuki wilayah Indonesia, yaitu di antaranya (Buku Keimigrasian, 2011); 
Nakhoda: Jurnal IImu Pemerintahan

Vol. 20 No. 01 Tahun 2021 Halaman 80-92

e-ISSN: 2656-5277 | p-ISSN: 1829-5827

- $\quad$ Izin Tinggal Kunjungan (ITK)

Jenis Visa yang digunakan oleh warga negara asing yang akan masuk ke wilayah Indonesia dan berlaku selama 30 Hari dan dapat di perpanjang selama empat kali dengan izin dari Keimigrasian Republik Indonesia. Visa jenis ini hanya dapat digunakan sebagai rangka kunjungan seperti Wisata, Keluarga \& Sosial, Tugas Pemerintahan, Study banding, Jurnalistik yang telah mendapat izin dari instansi yang berwenang, pembicaraan bisnis, seminar atau ceramah, pameran internasional, Pemegang Visa jenis ITK harus memiliki penjamin Warga Negara Indonesia, instansi atau korporasi yang menjamin seluruh kegiatan WNA dalam wilayah Indonesia sesuai jenis visa yang dimiliki.

- Izin Tinggal Terbatas (ITAS)

Jenis Visa izin bekerja untuk WNA yang digunakan untuk tinggal dan bekerja di wilayah Indonesia untuk waktu yang lama yaitu selama 6 bulan dan dapat di perpanjang selama empat kali. Selain untuk bekerja, ITAS dapat digunakan untuk penanaman modal asing, mengikuti pelatihan atau pelatihan ilmiah, keluarga, dan pendidikan. Pemegang Visa jenis ITAS harus memiliki penjamin Warga Negara Indonesia, instansi atau korporasi yang menjamin seluruh kegiatan WNA dalam wilayah Indonesia sesuai jenis visa yang dimiliki.

- $\quad$ Izin Tinggal Tetap (ITAP)

Jenis Visa ini diberikan kepada orang asing pemegang Visa Tinggal Terbatas yang telah lama menetap di Indonesia selama 5 tahun berturut-turut terhitung sejak diberikannya Izin Tinggal Terbatas. Izin Tinggal Tetap diperoleh berjenjang setelah lama memiliki izin tinggal terbatas. Pengalihan izin tersebut dapat diberikan atas permohonan orang asing yang bersangkutan. Izin Tinggal Tetap diberikan oleh Direktur Jenderal Imigrasi atas nama Menteri Hukum dan HAM.

Memasuki masa pemerintahan Joko Widodo sebagai Presiden Republik Indonesia membuat Kebijakan baru pada bidang keimigrasian dengan meresmikan Kebijakan Bebas Visa Kunjungan Indonesia pada tanggal 2 Maret 2016 yang telah di tanda tangani dalam Perpres Nomor 21 Tahun 2016 dengan hadirnya Menteri Hukum dan Ham Yasonna H. Laoly, di mana tercatat 169 Negara berhak mendapatkan izin tinggal dengan pengecualian hanya dapat digunakan untuk keperluan Wisata serta keperluan bisnis dan dapat digunakan selama 30 Hari tanpa bisa di perpanjang (Hukumonline, 2016).

Ada sejumlah syarat bagi para wisatawan yang harus dipenuhi untuk mendapatkan izin mengambil Bebas Visa Kunjungan (Buku Keimigrasian, 2011), di antaranya ;

- Memiliki paspor dengan masa berlaku paling singkat enam bulan.

- Memiliki tiket kembali atau tiket untuk melanjutkan perjalanan ke negara lain.

- Tidak dapat diperpanjang atau dialihstatuskan menjadi izin tinggal lainnya.

- Melakukan Kegiatan kunjungan seperti wisata, kunjungan keluarga, sosial dan seni budaya, tugas pemerintahan, dan keperluan bisnis lainnya.

Pemeriksaan warga negara asing dilakukan di Bandar Udara dan Pelabuhan yang dilakukan oleh petugas keimigrasian di terminal kedatangan internasional dengan pengambilan foto wajah dan pemindai sidik jari bagi tiap warga negara asing. Warga asing juga melakukan proses wawancara untuk mengetahui tujuan kedatangan warga negara asing tersebut masuk ke dalam Indonesia serta memeriksa kelengkapan dokumen sebagai syarat pengambilan Bebas Visa Kunjungan.

Dengan adanya kebijakan bebas visa kunjungan ini dapat menjadi kemudahan untuk wisatawan mancanegara untuk masuk ke wilayah negara Indonesia dengan diberikan kemudahan tanpa biaya administrasi bagi 169 Negara yang telah terdaftar. Peningkatan wisatawan 
mancanegara di Sulawesi Selatan pasca diresmikannya kebijakan bebas visa kunjungan mengalami peningkatan yang signifikan terbukti dari tahun 2016 sampai tahun 2018 dan berdampak kepada pendapatan devisa Indonesia yang mengalami peningkatan dari tahun 2016 sampai tahun 2019. Hal ini sebagaimana disajikan pada Gambar 1.

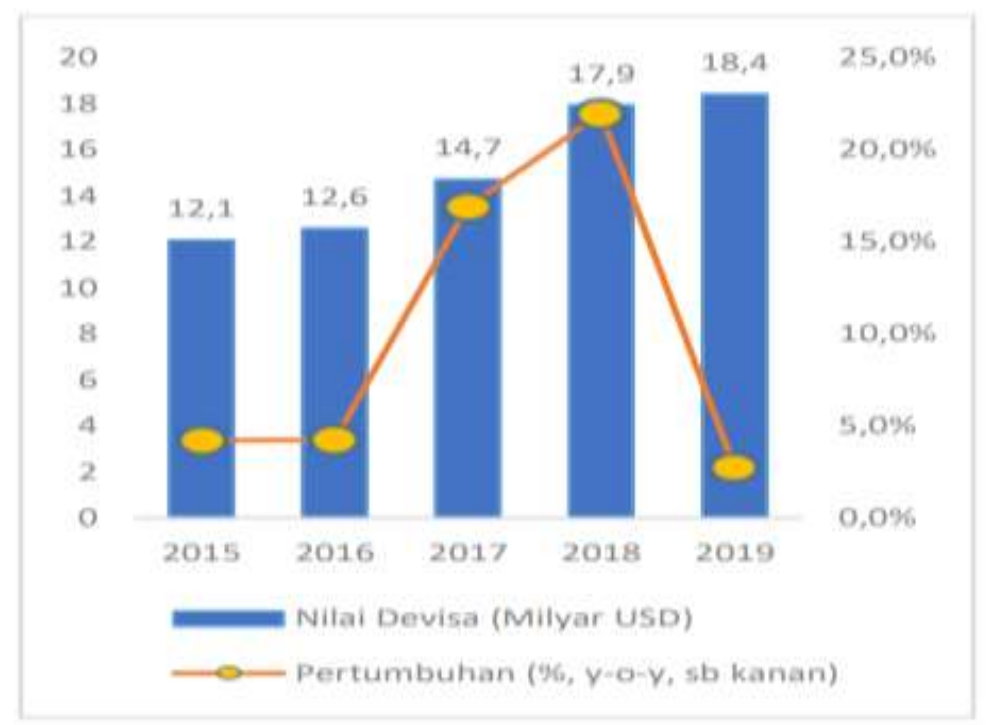

Gambar 1. Pendapatan Devisa Sektor Pariwisata Indonesia Periode 2015-2019 Sumber : Badan Pusat Statistika. Data Diolah. (2020)

Pada Gambar 1 dapat dilihat bahwa pendapatan devisa sektor Pariwisata Indonesia mengalami peningkatan dari tahun 2015 sampai tahun 2018. Pada triwulan IV di tahun 2019, turis asing yang melakukan kunjungan ke Indonesia mencapai 4 juta orang atau meningkat sebesar 3,9 persen dibandingkan dengan triwulan IV tahun 2018. Namun pertumbuhan ini tidak setinggi triwulan sebelumnya (14,4 persen) karena dampak pemilu, seperti ditunjukkan oleh penurunan wisman ke Jakarta dan pelambatan kunjungan wisman ke Bali. Kunjungan wisatawan mancanegara dari hampir seluruh negara sebenarnya meningkat dibandingkan dengan periode sebelumnya, meskipun kontribusi wisatawan asing masing-masing negara hanya tumbuh sebesar 10 persen. Secara umum, jumlah kedatangan wisatawan asing pada tahun 2019 meningkat menjadi 16,1 juta orang, namun pertumbuhannya melambat yakni hanya sebesar 2 persen dan jauh lebih kecil daripada tahun 2018 yang sebesar 13 persen. Total kunjungan wisman tahun 2019 sebesar 16,1 juta (Bappenas, 2020).

Kunjungan wisatawan mancanegara yang terus meningkat dari tahun 2016 tidak lepas dari pengaruh Kebijakan Bebas Visa Kunjungan dan Strategi Branding "Wonderful Indonesia", terbukti dari pendapatan devisa yang meningkat secara signifikan tiap tahunnya mengalahkan kelapa sawit pada sektor perekonomian menjadikan sektor pariwisata menjadi sektor unggulan di Indonesia dalam pendapatan devisa. Di Sulawesi Selatan sendiri jumlah wisatawan mancanegara tiap tahunnya terus meningkat dari tahun 2016 sampai 2019.

Meningkatnya jumlah kunjungan wisatawan mancanegara banyak disalahgunakan oleh orang asing penerima bebas visa kunjungan. Dengan tidak mematuhi peraturan perundangundangan dan ketentuan-ketentuan yang ada, yakni maraknya orang asing yang melebihi batas izin tinggal di Indonesia (overstay) dan melakukan kegiatan bekerja di Indonesia secara tidak resmi (Prayulianda \& Antikowati, 2019). 
Nakhoda: Jurnal IImu Pemerintahan

Vol. 20 No. 01 Tahun 2021 Halaman 80-92

e-ISSN: 2656-5277 | p-ISSN: 1829-5827

\section{Implikasi Kebijakan Bebas Visa Kunjungan Terhadap Statistik Wisatawan Asing Di Kota Makassar}

Perkembangan pariwisata di Indonesia selalu di dominasi oleh Indonesia bagian barat, di mana sarana dan prasarana di sektor pariwisata lebih berkembang dan lebih dikenal oleh wisatawan mancanegara dibandingkan dengan Indonesia bagian timur. Hal ini juga terlihat dari pembangunan di sektor pariwisata, kawasan Jawa dan Bali menjadi pusat utama pembangunan kepariwisataan. Sebenarnya jika dilihat dari potensi sumber daya alam sebagai tujuan kedatangan wisatawan, maka keindahan dan eksotisnya pemandangan alam di kawasan timur Indonesia lebih baik di bandingkan kawasan Indonesia bagian barat. Potensi tersebut memiliki peluang yang besar untuk dikembangkan. Namun keunggulan tersebut tidak serta merta dapat membawa Indonesia Timur sebagai destinasi wisata utama, karena adanya beberapa masalah seperti, kurangnya infrastruktur, sumber daya manusia terbatas, dan lain sebagainya. Dengan alasan seperti itu maka Jawa dan Bali masih menjadi daerah tujuan wisatawan mancanegara yang paling dominan ketimbang Indonesia bagian timur, seperti misalnya Sulawesi Selatan.

Sulawesi Selatan merupakan pusat dari Kawasan Timur Indonesia dan ditetapkan sebagai salah satu destinasi wisata unggulan di Indonesia setelah Jawa dan Bali. Sulawesi Selatan memiliki potensi wisata yang diharapkan mampu mendorong pertumbuhan ekonomi dan menunjang pembangunan serta memberikan kontribusi besar bagi Pendapatan Asli Daerah (PAD). Sulawesi Selatan yang dikenal sebagai provinsi yang kaya akan keberagaman budaya serta suku dan adat istiadatnya. Keberagaman ini dapat menjadi acuan untuk para wisatawan datang ke Sulawesi Selatan untuk destinasi wisata. Kunjungan wisatawan yang datang ke Sulawesi Selatan bukan hanya wisatawan dari nusantara, tetapi juga kunjungan mancanegara yang datang dari berbagai negara datang untuk melihat kekayaan yang dimiliki Provinsi Sulawesi Selatan, khususnya di Kota Makassar.

Makassar memiliki berbagai objek unggulan dalam sektor pariwisata di antaranya Pantai Losari, Pulau Samalona, Trans Studio Makassar, Pula Lae-Lae, Pulau Kodingareng Keke, Kampung Lakkang, Bugis Waterpark, Pelabuhan Tradisional Paotere, Benteng Somba Opu dan Benteng Fort Rotterdam. Daya tarik wisata bukan hanya alasan dibalik peningkatan kunjungan wisatawan, tapi juga pagelaran kebudayaan di Makassar menjadi salah satu penyebab meningkatnya kunjungan wisatawan. Pagelaran kebudayaan seperti Eight Festival (F8) dan Makassar International Writer Festival menjadi daya tarik tersendiri bagi wisatawan baik itu wisatawan domestik maupun wisatawan mancanegara (Makassar, 2019).

Dinas Kebudayaan dan Pariwisata Provinsi Sulawesi Selatan berperan dalam melestarikan dan mengembangkan kebudayaan dan pariwisata untuk menumbuhkan pemahaman masyarakat terhadap kebudayaan dan pariwisata lokal. Dengan menumbuhkan kesadaran masyarakat tentang pentingnya melestarikan budaya dan potensi alam, maka kehidupan masyarakat bisa tumbuh harmonis bersama tujuan pemerintah untuk memajukan potensi daerah sebagai tujuan pariwisata. Eksistensi masyarakat yang menjaga nilai autentik sebuah budaya lokal memiliki peran yang sangat besar dalam sektor pengembangan pariwisata daerah.

Kawasan yang dianggap memiliki potensi pariwisata di Makassar adalah resor-resor pulau kecil di Makassar, kawasan Benteng Somba Opu, kawasan Fort Rotterdam di Makassar, pengembangan wisata bahari pulau Kapoposang, kawasan wisata pantai Barombong dan produk pariwisata di Kota Makassar. Keragaman daya tarik wisata serta berbagai macam pagelaran budaya di tiap daerah yang dimiliki oleh Kota Makassar tidak membuat jumlah wisatawan mancanegara meningkat. Pada tahun 2012 wisatawan mancanegara yang berkunjung ke Kota Makassar justru mengalami penurunan dari angka 23.385 ke angka 19.881. naik turunnya tingkat kunjungan wisatawan asing ke Kota Makassar ini terjadi hingga tahun 2015. Peningkatan jumlah wisatawan mulai terlihat pada tahun 2016, di mana pada tahun tersebut telah diberlakukan kebijakan Bebas Visa kunjungan Singkat yang mempermudah wisatawan mancanegara untuk 
Nakhoda: Jurnal IImu Pemerintahan

Vol. 20 No. 01 Tahun 2021 Halaman 80-92

e-ISSN: 2656-5277 | p-ISSN: 1829-5827

melakukan perjalanan ke Indonesia Jumlah Wisatawan yang berkunjung ke Makassar sebagaimana disajikan pada Tabel 1.

Tabel 1. Jumlah Kunjungan Wisatawan Mancanegara dan Wisatawan Nusantara di Makassar Tahun 2011-2018

\begin{tabular}{ccc}
\hline Tahun & $\begin{array}{c}\text { Wisatawan } \\
\text { Mancanegara }\end{array}$ & $\begin{array}{c}\text { Wisatawan } \\
\text { Nusantara }\end{array}$ \\
\hline 2011 & 23.385 & 3.027 .096 \\
2012 & 19.881 & 3.650 .684 \\
2013 & 24.988 & 3.756 .627 \\
2014 & 21.211 & 3.528 .086 \\
2015 & 53.879 & 3.771 .067 \\
2016 & 85.644 & 4.688 .681 \\
2017 & 102.462 & 5.187 .521 \\
2018 & 105.447 & 5.461 .677 \\
\hline
\end{tabular}

Sumber : Dinas Kebudayaan dan Pariwisata Sulawesi Selatan. Data diolah. (2020)

Pada Tabel 1 dapat dilihat bahwa terjadi peningkatan yang signifikan dari tahun 2014 ke tahun 2015, dan terus meningkat hingga tahun 2018. Kebijakan Bebas Visa Kunjungan Singkat ini dinilai berhasil meningkatkan jumlah wisatawan asing yang berkunjung ke Kota Makassar. Tingginya tingkat kunjungan wisatawan tersebut disebabkan oleh kebijakan nasional negara Indonesia nyang diimplementasikan guna mencapai suatu kepentingan yaitu meningkatnya pendapatan negara di bidang pariwisata. Peningkatan tersebut tentu akan seiring sejalan dengan terus bertambahnya volume kunjungan wisatawan asing. Namun, kebijakan nasional tersebut menemui hambatannya ketika pada tahun 2019 tarif batas atas dan tarif batas bawah penerbangan menjadi tinggi.

Perubahan tarif batas atas yang diatur dalam Keputusan Menteri Perhubungan Nomor KM 106 Tahun 2019 tentang Tarif Batas Atas Penumpang Pelayanan Kelas Ekonomi Angkutan Udara Niaga Berjadwal Dalam Negeri menjadi salah satu alasan menurunnya wisatawan mancanegara yang berkunjung. Alasan lainnya adalah Bencana alam (gempa dan gunung meletus) sehingga terjadinya pembatalan kunjungan wisman, Musibah jatuhnya pesawat Lion Air JT-610, Polemik "Zero Dollar Tour” yang terjadi sempat membuat iklim pariwisata di Bali turun, Kota Makassar belum menjadi 10 destinasi pariwisata unggulan oleh Kementerian Pariwisata sehingga promosi destinasi Kota Makassar sangat lemah di luar negeri, Kegiatan pesta demokrasi politik baik tingkat daerah maupun nasional (Said, 2019).

Akibat dari kenaikan harga tiket pesawat tersebut, tren kunjungan wisatawan asing ke Kota Makassar mengalami penurunan sebanyak $0,41 \%$ per bulan. Hal ini sebagaimana disajikan pada Gambar 2. 


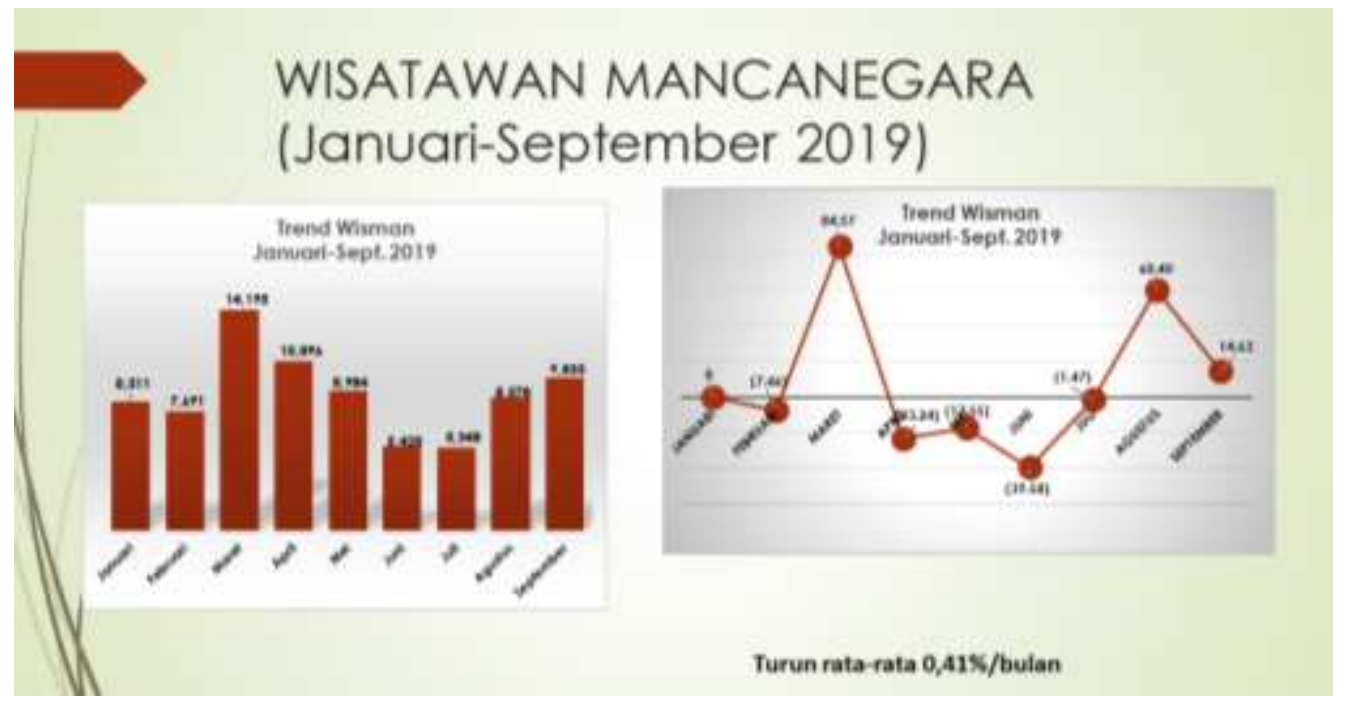

Gambar 2. Statistik Kunjungan Wisatawan Mancanegara

Sumber : Dinas Pariwisata Kota Makassar. Data diolah. (2020)

Berkurangnya wisatawan mancanegara yang berkunjung ke Kota Makassar mempengaruhi bisnis perhotelan di Kota Makassar. Akibat kurangnya turis asing yang datang, tingkat hunian hotel yang ada di Kota Makassar menurun sebesar 21\% dari tahun 2018. Hal ini sebagaimana disajikan pada Gambar 3.

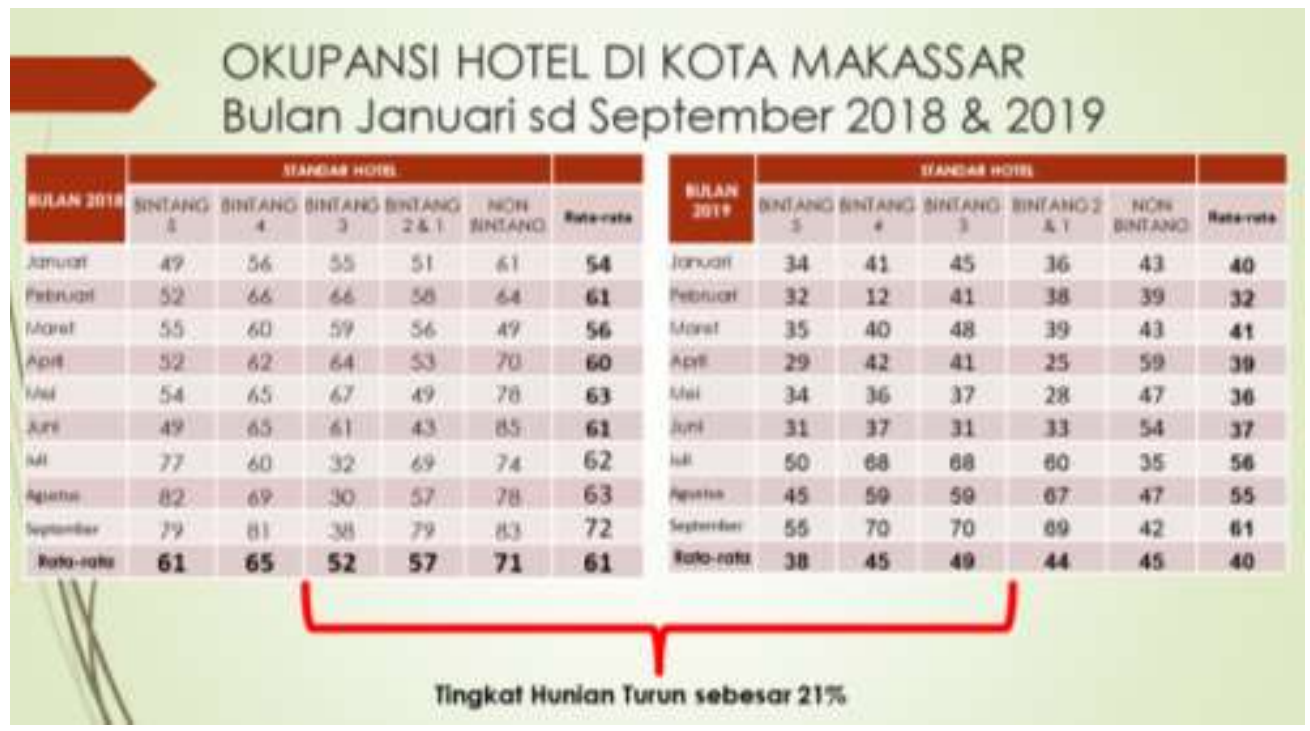

Gambar 3. Tingkat Hunian Hotel di Kota Makassar

Sumber : Dinas Pariwisata Kota Makassar. Data diolah. (2020)

Berdasarkan Gambar 3, terlihat bahwa kebijakan bebas visa kunjungan tidak lagi memberikan pengaruh terhadap minat kunjungan turis asing ke Kota Makassar. Selain mengandalkan kebijakan nasional, Pemerintah Kota Makassar seharusnya bisa mengeluarkan formula-formula yang tepat untuk mendukung kebijakan nasional tersebut. Salah satu cara yang bisa dilakukan adalah dengan melakukan promosi wisata Kota Makassar ke negara lain.

Salah satu langkah sederhana yang bisa dilakukan Pemerintah Kota Makassar melalui Dinas Kebudayaan dan Pariwisata Kota Makassar adalah dengan melakukan promosi pariwisata di luar negeri. Promosi merupakan salah satu cara efektif yang bisa dilakukan dalam menarik minat wisatawan asing, namun promosi pariwisata di Sulawesi Selatan minim dilakukan oleh pejabat setempat karena kurangnya anggaran. Direktur eksekutif BPBD Sulsel Hendra Nick 
Nakhoda: Jurnal IImu Pemerintahan

Vol. 20 No. 01 Tahun 2021 Halaman 80-92

e-ISSN: 2656-5277 | p-ISSN: 1829-5827

Arthur mengatakan bahwa lokasi belanja iklan promosi kepariwisataan di Sulsel sangat kecil bila dilihat dalam kurun waktu lima tahun terakhir, sehingga berdampak pada tidak maksimalnya promosi (Fatir, 2019).

Pada tahun 2017 Dinas Pariwisata Kota Makassar mengadakan promosi wisata pada World Travel Market London di London, Inggris. Menurut Kepala Dinas Pariwisata Kota Makassar Rusmayani Madjid mengatakan, ini adalah kali pertama Pemerintah Kota Makassar ikut di WTM London, di mana kurang lebih 2 Tahun terakhir kegiatan promosi di luar negeri ditiadakan. Dengan diadakannya pameran di luar negeri diharapkan statistik kunjungan wisatawan mancanegara ke Makassar bisa mengalami peningkatan.

\section{Dampak terhadap Keamanan di Kota Makassar}

Dalam rangka mencegah terjadinya pelanggaran perlu dilakukan pengawasan secara ketat dan konsisten. Pengawasan terhadap orang asing yang melakukan kunjungan ke Indonesia sudah diatur dalam Peraturan Presiden Nomor 21 Tahun 2016 tentang Bebas Visa Kunjungan. Namun, dalam pelaksanaannya masih banyak terjadi pelanggaran dan penyalahgunaan ketentuan keimigrasian yang dilakukan oleh orang asing (Setiadi \& Afrizal, 2019). Arus imigrasi yang begitu deras membuat pemerintah harus membuat berbagai kebijakan preventif untuk mencegah potensi pelanggaran yang mungkin terjadi.

Keimigrasian selaku instansi yang memiliki wewenang dalam pengawasan warga negara asing tersebut bekerja secara penuh menurut Peraturan Menteri Hukum dan Hak Asasi Manusia Nomor 50 Tahun 2016 Tentang Tim Pengawasan Orang Asing yang menyatakan dalam rangka pengawasan orang asing Menteri membentuk tim koordinasi pengawasan orang asing yang di bentuk di tingkat pusat, tingkat Provinsi Daerah dan Wilayah atau Daerah Kecamatan yang terdapat Kantor Imigrasi. Anggota Tim Koordinasi Pengawasan Orang Asing terdiri atas wakil dari Badan atau Instansi Pemerintah yang bidang tugasnya menyangkut pengawasan orang asing dengan resmi membentuk Tim Pengawasan Orang Asing (TIMPORA).

Upaya yang dilakukan Kantor Imigrasi Kelas I Makassar membentuk Tim Pengawasan Orang Asing (TIMPORA) di 11 Wilayah Kabupaten/Kota yaitu Kota Makassar, Kabupaten Maros, Kabupaten Pangkajene, Kabupaten Gowa, Kabupaten Takalar, Kabupaten Jeneponto, Kabupaten Bantaeng, Kabupaten Bulukumba, Kabupaten Sinjai, Kabupaten Selayar, Kabupaten Bone. TIMPORA memiliki tugas memberikan saran serta pertimbangan kepada instansi dan lembaga pemerintahan terkait hal-hal yang berkaitan dengan pengawasan orang asing (PORA, 2016).

Selain itu, selama pemberlakuan BVKS jumlah wisatawan mancanegara yang berkunjung ke Kota Makassar mengalami peningkatan sehingga pengawasan terhadap tingkah laku orang asing yang berkunjung ke Kota Makassar juga harus diperhatikan oleh pejabat setempat. Bebas Visa yang diberikan oleh Indonesia nyatanya disalahgunakan oleh wisatawan asing. Alih-alih melakukan kunjungan wisata, para wisman justru memanfaatkan peluang ini untuk mencari pekerjaan di Kota Makassar.

Penyalahgunaan izin tinggal dan overstay bisa diatasi dengan Pengawasan oleh pihak keimigrasian, seperti di Provinsi Sulawesi Selatan. Pengawasan dari Kantor Imigrasi Kelas I Makassar tentu sangat berperan penting dalam pemberian izin masuk bagi orang asing di wilayah Indonesia. Faktor sumber daya manusia juga penting dalam pengawasan tersebut, sebab kecakapan dalam menjalankan tugas memberikan efek yang signifikan dalam mengawasi orang asing yang masuk. Ini menjadikan hal yang sangat penting dalam proses masuk dan keluarnya warga negara asing di Indonesia. Prosedur pengawasan yang di lakukan petugas Kantor Imigrasi Kelas I Makassar dalam pemeriksaan warga negara asing yang masuk dan keluar dari Negara Kesatuan Republik Indonesia memiliki tujuan untuk mengetahui ada tidaknya pelanggaran keimigrasian yang dilakukan. 
Prosedur pengawasan di Kantor Imigrasi Kelas I Makassar dilakukan oleh Seksi Pengawasan dan Tindakan Keimigrasian (WASDAKIM) dengan cara administratif, seperti pemeriksaan kelengkapan dokumen permohonan izin tinggal yang masuk ke kantor Imigrasi kelas I Makassar. Dari berkas yang ada apabila ada suatu kejanggalan terhadap permohonan tersebut maka akan dilakukan pemeriksaan lapangan disertai dengan penindakan seperti deportasi atau penanganan lebih lanjut.

Tabel 2.Pengurangan Data Izin Tinggal Tertinggi Berdasarkan Kebangsaan Tahun 2018

\begin{tabular}{clcccc}
\hline No. & Kebangsaan & $\begin{array}{c}\text { Meninggal } \\
\text { Dunia }\end{array}$ & Pengembalian & Penindakan & Pemulangan \\
\hline 1 & China & 0 & 142 & 0 & 0 \\
2 & Timor Leste & 1 & 107 & 0 & 0 \\
3 & Australia & 1 & 82 & 1 & 0 \\
4 & Korea Selatan & 1 & 71 & 1 & 0 \\
5 & Thailand & 0 & 56 & 1 & 0 \\
6 & Amerika Serikat & 1 & 55 & 1 & 0 \\
7 & Malaysia & 0 & 54 & 5 & 0 \\
& Total & 4 & 567 & 9 & 0 \\
\hline
\end{tabular}

Sumber : Kantor Imigrasi Kelas I Makassar. Data diolah. (2020)

Pada Tabel 2 dapat dilihat pengurangan data izin tinggal berdasarkan kebangsaan tahun 2018 dan dari data di atas menunjukkan hampir semua negara di atas termasuk ke dalam kebijakan bebas visa kunjungan. Warga asing yang berasal dari Tiongkok paling banyak dideportasi ke negara asalnya oleh Kantor Imigrasi Kelas I Makassar. Dari data di atas ada beberapa warga negara asing yang melakukan pelanggaran paling banyak adalah melewati batas izin tinggal (overstay).

Berdasarkan beberapa pelanggaran dalam penggunaan fasilitas bebas visa kunjungan di ruang lingkup Kantor Imigrasi Kelas I Makassar tentu dalam penegakan hukum harus dilaksanakan terhadap pelanggaran keimigrasian. Penjatuhan sanksi diatur dalam UndangUndang Nomor 6 Tahun 2011 Tentang Keimigrasian. Sanksi yang diberikan berdasarkan dengan porsi masing-masing seberapa besar kesalahan yang dilakukan oleh pelanggarnya. Dengan adanya pemberian sanksi tentu akan memberikan efek jera terhadap pelakunya dan diharapkan tidak melakukannya kembali.

\section{Kesimpulan}

Kebijakan bebas visa kunjungan merupakan usaha pemerintah untuk meningkatkan kunjungan wisatawan mancanegara serta meningkatkan pendapatan devisa Negara. Keimigrasian selaku instansi yang memiliki wewenang dalam penanganan izin tinggal warga negara asing mendapatkan dampak yang besar dikarenakan kunjungan warga negara asing tiap tahunnya meningkat. Dinas Pariwisata juga mendapatkan dampak yang besar yang di mana kunjungan wisatawan mancanegara di Indonesia juga ikut meningkat terkait kebijakan bebas visa kunjungan dan juga strategi branding Wonderful Indonesia yang dilakukan oleh Dinas Pariwisata sebagai bentuk usaha dalam peningkatan kunjungan wisatawan mancanegara.

Kebijakan Nasional ini harus diimbangi dengan strategi pemerintah Kota Makassar dalam memaksimalkan potensi pariwisatanya agar kunjungan wisatawan mancanegara bisa terus meningkat dan dapat bersaing dengan objek wisata yang terletak di kota lain di Indonesia. Formulasi peraturan daerah juga diperlukan agar dampak Kebijakan Bebas Visa Kunjungan Singkat memberikan dampak positif dalam skala yang lebih luas. Penurunan harga tiket pesawat dan pengoptimalan promosi pariwisata Kota Makassar merupakan sebuah catatan penting yang harus dilakukan oleh pemerintah setempat. Selain itu, pemerintah setempat juga harus 
Nakhoda: Jurnal IImu Pemerintahan

Vol. 20 No. 01 Tahun 2021 Halaman 80-92

e-ISSN: 2656-5277 | p-ISSN: 1829-5827

meningkatkan sistem pengawasan terhadap orang asing yang berkunjung agar tidak menyalahgunakan Kebijakan Bebas Visa Kunjungan dengan memanfaatkan izin tersebut untuk mencari kerja dan tinggal lebih lama dari batas waktu yang telah ditentukan oleh Pemerintah Kota Makassar.

\section{Ucapan Terima Kasih}

Puji Syukur penulis ucapkan kepada Tuhan Yang Maha Tunggal atas berkat rahmat dan hidayah-Nya sehingga penelitian ini dapat diselesaikan dengan baik. Tidak lupa penulis mengirimkan salam dan selawat kepada Sang Pembawa Cahaya Nabi Besar Muhammad SAW. Penelitian mengenai Kebijakan Bebas Visa Kunjungan di Kota Makassar ini tidak lepas dari pihak-pihak yang telah memberikan kontribusinya baik secara materiil maupun non materiil. Untuk itu, penulis ucapkan terima kasih yang sebesar-besarnya kepada Universitas Fajar yang telah mendanai penelitian ini, semoga tulisan ini bisa memberikan manfaat bagi perkembangan ilmu pengetahuan terkait dengan tema penelitian ini. Terima kasih juga kepada Dinas Pariwisata Kota Makassar yang telah bersedia untuk berkorepondensi dengan penulis terkait kebutuhan data penelitian ini.

\section{Daftar Pustaka}

A.J. Muljadi, M. (2009). Kepariwisataan dan Perjalanan. Raja Grafindo.

Bakry, U. S. (2016). Metode Penelitian Hubungan Internasional. Pustaka Pelajar.

Bappenas. (2020). Perkembangan Ekonomi Dunia dan Indonesia.

https://www.bappenas.go.id/files/2715/8529/3891/Laporan_Perkembangan_Ekonomi_Indo nesia_dan_Dunia_Triwulan_IV_2019.pdf.pdf

Budiardjo, M. (2003). Dasar-Dasar Ilmu Politik. Gramedia Pustaka utama.

Buku Keimigrasian, Peraturan Pelaksanaan Undang-Undang Nomor 6 Tahun 2011 Tentang Keimigrasian, (2011).

Consular Indonesia, O. (2019). Visa on Arrivals. Http://Consular.Indonesia-Ottawa.Org/ForeignCitizens/Visa-Information/Types-of-Visa/Visa-on-Arrival/.

Fatir, M. D. (2019). Direktur eksekutif BPBD Sulsel Hendra Nick Arthur. Antara Makassar, 1. https://makassar.antaranews.com/berita/108278/terkendala-anggaran-promosi-pariwisatasulsel-minim

Hamidi, J. (2015). Hukum Keimigrasian Bagi Orang Asing di Indonesia. Sinar Grafika.

Hukumonline. (2016). Daftar 169 Negara Visa Bebas Kunjungan.

Https://Www.Hukumonline.Com/Berita/Baca/Lt56efa1d8b3f51/Ini-Daftar-169-Negara-

Bebas-Visa-Kunjungan.

Jack C. Plano, R. O. (1969). The International Relations Dictionary. Rinehart and Winston.

Makassar, D. (2019). Destinations of Makassar. Https://Www.Tourism-

Makassar.Id/Kategori/Destination.

Matthew B. Miles, A. Michael Huberman, J. S. (2014). Qualitative Data Analysis (3rd ed.). SAGE.

Morgenthau, H. J. (1951). In Defense of the National Interest: A Critical Examination of American Foreign Policy. 283.

https://doi.org/https://journals.sagepub.com/doi/10.1177/000271625227900124

Pendit, N. S. (1990). Ilmu pariwisata : sebuah pengantar perdana. PT Prandnya Paramita.

PORA, T. (2016). Laporan Pelaksanaan Rapat Koordinasi Dan Pembentukan Tim Pengawasan Orang Asing (TIMPORA) Tingkat Provinsi Sulawesi Selatan Tahun 2016.

Prayulianda, H. A., \& Antikowati, A. (2019). Pengawasan Warga Negara Asing Penerima Bebas Visa Kunjungan dalam Perspektif Hukum Kewarganegaraan. Lentera Hukum, 6(1), 141.

https://doi.org/10.19184/ejlh.v6i1.8428

Robert Jackson, G. S. (2005). Pengantar studi hubungan internasional. Pustaka Pelajar. 
Nakhoda: Jurnal Ilmu Pemerintahan

Vol. 20 No. 01 Tahun 2021 Halaman 80-92

e-ISSN: 2656-5277 | p-ISSN: 1829-5827

Said, F. (2019). Analisis Sektor Pariwisata Kunjungan Wisatawan Di Kota Makassar.

Setiadi, W., \& Afrizal, R. A. (2019). Implikasi Kebijakan Bebas Visa Berdasarkan Peraturan Presiden Tentang Bebas Visa Kunjungan: Perspektif Ketenagakerjaan. Jurnal Ilmiah Kebijakan Hukum, 13(3), 311. https://doi.org/10.30641/kebijakan.2019.v13.311-322

Soenarko. (2003). Public Policy:Pengertian Pokok Untuk Memahami Dan Analisa Kebijaksanaan Pemerintah. Airlangga University Press. 